(c) American Dairy Science Association, 2006.

\title{
Intake and Performance of Lactating Cows Grazing Diverse Forage Mixtures
}

\author{
K. J. Soder,* M. A. Sanderson, ${ }^{\star}$ J. L. Stack, $†$ and L. D. Muller† \\ *USDA/Agricultural Research Service, Pasture Systems and Watershed Management Research Unit, \\ University Park, PA 16802-3702 \\ †Department of Dairy and Animal Science, The Pennsylvania State University, University Park 16802
}

\begin{abstract}
Twenty multiparous Holstein cows in midlactation grazed pastures of 4 forage mixtures in a 12 -wk study repeated during 2 grazing seasons to determine if forage mixture complexity affected intake and productivity of lactating dairy cows. The forage mixtures were 1) orchardgrass plus white clover [2 species (SP)]; 2) orchardgrass, white clover, and chicory (3SP); 3) orchardgrass, tall fescue, perennial ryegrass, red clover, birdsfoot trefoil, and chicory (6SP); and 4) 6SP mixture plus white clover, alfalfa, and Kentucky bluegrass (9SP). Total herbage intake was similar among forage mixtures, averaging $12.0 \mathrm{~kg} / \mathrm{d}$ across all forage mixtures and years. Milk production and composition were not affected by forage mixture or year, and averaged $34.6 \mathrm{~kg} / \mathrm{d}, 3.4 \%$, and $2.8 \%$ for milk production, milk fat percentage, and milk protein percentage, respectively. The conjugated linoleic acid content of milk fat was higher for cows that grazed the 3SP, 6SP, and 9SP mixtures than from cows that grazed the 2SP mixture (1.02 vs. $0.87 \mathrm{~g}$ of conjugated linoleic acid/100 g of fatty acids, respectively). Blood glucose, blood urea nitrogen, and nonesterified fatty acids were not affected by forage mixture and averaged $69.2 \mathrm{mg} / \mathrm{dL}$, $13.4 \mathrm{mg} / \mathrm{dL}$, and $277.5 \mu \mathrm{Eq} / \mathrm{L}$, respectively. The results of this study indicate that altering the forage mixture in pastures did not affect dry matter intake, milk production, or blood metabolite profiles of lactating cows. The use of complex mixtures of forages in grazing systems should not affect dairy cow performance.
\end{abstract}

Key words: forage mixture, grazing, intake, milk production

\section{INTRODUCTION}

Animal productivity in a grazing system is a function of the output per animal (e.g., milk per cow, weight gain per head) and the number of animals that a unit

Received July 11, 2005.

Accepted December 14, 2005.

${ }^{1}$ Corresponding author: Kathy.Soder@ars.usda.gov of grazing land will support. Voluntary DMI along with stocking rate are key determinants of animal performance on pasture (Fales et al., 1995; Kolver and Muller, 1998). Dry matter intake is strongly affected by multiple factors, including the amount of herbage on offer (Bargo et al., 2002a) as well as its acceptance by the animal (Ganskopp et al., 1997). The amount of herbage grown and consumed is affected by the botanical composition and population of the pastures and the morphology and structure of the sward (Dalley et al., 1999).

Greater plant diversity in grassland plant communities has been linked to increased primary (plant) production (Sanderson et al., 2005), greater stability in response to disturbance (Minns et al., 2001), and reduced weed pressure (Tracy and Sanderson, 2004). With some livestock operations opting for less capitalintensive production systems, emphasis has been placed on low-input pasture systems that rely on complex species mixtures to produce forage. Recent work with forage mixtures in clipped plots showed increased herbage yield in complex vs. simple mixtures of forages (Deak et al., 2004; Tracy and Sanderson, 2004). Although clipped plots provide the opportunity to screen several forage mixtures, the effects of primary (forage) productivity on secondary (animal) productivity are relatively unknown. Very few studies exist in the literature that evaluate the performance of dairy cows with forage mixtures, and nearly all are limited to simple one grass-one legume mixtures, with contradictory results (Wedin et al., 1965; Harris et al., 1997; Phillips and James, 1998; Rutter et al., 2004). Evaluation of more complex forage mixtures on performance of dairy cows has not been evaluated. Therefore, a study was designed to determine the effect of forage mixture complexity in pastures on intake and productivity of grazing lactating dairy cows.

\section{MATERIALS AND METHODS}

\section{Experimental Design, Cows, and Forage Mixtures}

The experiment was conducted under the approval of The Pennsylvania State University Animal Care 
and Use Committee. Twenty multiparous Holstein cows [BW $648 \mathrm{~kg} \pm 74 \mathrm{~kg}$; milk yield, $46.7 \mathrm{~kg} \pm 11.5$ $\mathrm{kg}$; parity, $3.1 \pm 1.1$; DIM, $109 \pm 21$ (mean \pm SD)] were used in a 12 -wk study repeated over 2 grazing seasons beginning on May 5, 2002, and May 6, 2003, respectively. Cows were selected from the herd of The Pennsylvania State University Dairy Cattle Research and Education Center (University Park, PA). Cows were blocked by lactation number and milk yield. These cow blocks were then treated as a unit, remaining together and changing forage mixture as a single unit throughout the experiment. Due to stage of lactation requirements, only 6 cows from the first year were used during the second grazing season.

The forage mixtures compared were 1) 2-species mixture (2SP)-orchardgrass (Dactylis glomerata L.) and white clover (Trifolium repens L.); 2) 3-species mixture (3SP)—orchardgrass, white clover, and chicory (Cichorium intybus L.); 3) 6-species mixture (6SP)-orchardgrass, tall fescue (Festuca arundinacea Schreb.), perennial ryegrass (Lolium perenne L.), red clover (Trifolium pratense L.), birdsfoot trefoil (Lotus corniculatus L.), and chicory; and 4) 9-species mixture (9SP)—6SP mixture plus white clover, alfalfa (Medicago sativa L.), and Kentucky bluegrass (Poa pratensis L.). Two 1-ha pastures of each forage mixture were established in the fall of 2001 . No fertilizer was applied during establishment or for the duration of the trial. Biosecurity policies at The Pennsylvania State University precluded the use of additional dry cows or heifers in rotation with the lactating cows to clean up residual forage. If excessive ungrazed forage remained after grazing, pastures were clipped to maintain a similar vegetative state in each paddock and the clipped residue was left in place. Mechanical harvest or clipping of excess forage is a common practice on grazing dairies in the northeastern United States to maintain the pasture in a vegetative state and control weeds.

The experimental design was a randomized complete block. Cow blocks (5 cows/block) were assigned to 1 of 4 forage mixtures for each 3 -wk period. Cow blocks switched forage mixtures every $3 \mathrm{wk}$, so by the end of the experiment, all cow blocks had grazed all 4 forage mixtures.

Two weeks before the start of the experiment (midApril of each year), cows were adapted to pasture. Cows had access to the experimental pastures (for exposure to all forage species) for $2 \mathrm{~h}$ during the first adaptation day. This was increased by 1 to $2 \mathrm{~h}$ each day until the cows had 24-h access to pasture before the beginning of the experimental periods. Cows were individually fed a corn-based concentrate at a rate of $1 \mathrm{~kg}$ of DM/4 kg of milk (based on pretrial milk yield)
Table 1. Ingredient and chemical composition (mean \pm SD) of the concentrate mixture (DM basis)

\begin{tabular}{lc}
\hline Item & \\
\hline Ingredient composition, \% & \\
Dry ground corn & 41.7 \\
Wheat middlings & 18.8 \\
Soyhulls & 16.7 \\
Corn distillers (dark) & 8.6 \\
Citrus pulp & 5.2 \\
Heat-treated soybean meal & 3.1 \\
Soybean meal (48\%) & 2.9 \\
Plain salt & 0.90 \\
Magnesium oxide & 0.73 \\
Calcium carbonate & 0.61 \\
Dicalcium phosphate & 0.34 \\
Agmate (KMS) & 0.20 \\
Selenium premix (0.06\%) & 0.11 \\
Trace mineral premix ${ }^{2}$ & 0.06 \\
Vitamins A, D, E & 0.05 \\
Chemical composition & \\
DM, \% & \\
OM, \% of DM & $95.2 \pm 1.2$ \\
CP, \% of DM & $90.3 \pm 0.9$ \\
Soluble CP, \% of CP & $14.1 \pm 0.6$ \\
TNC, \% of DM & $15.9 \pm 0.7$ \\
NDF, \% of DM & $41.8 \pm 1.8$ \\
ADF, \% of DM & $28.9 \pm 1.1$ \\
IVDMD, \% of DM & $17.4 \pm 0.8$ \\
\hline & $74.0 \pm 3.8$ \\
\hline $199 \%$. &
\end{tabular}

${ }^{1} 99 \%$ ash, $11.2 \% \mathrm{Mg}, 18.4 \% \mathrm{~K}$, and $22.4 \% \mathrm{~S}$.

${ }^{2} 98.6 \%$ ash; $0.58 \% \mathrm{Ca} ; 1,390 \mathrm{mg} / \mathrm{kg} \mathrm{Co} ; 41,649 \mathrm{mg} / \mathrm{kg} \mathrm{Cu} ; 2,780$ $\mathrm{mg} / \mathrm{kg} \mathrm{I} ; 10,412 \mathrm{mg} / \mathrm{kg} \mathrm{Fe} ; 124,947 \mathrm{mg} / \mathrm{kg} \mathrm{Mn} ; 16.1 \% \mathrm{~S}$, and 124,947 $\mathrm{mg} / \mathrm{kg} \mathrm{Zn}$.

${ }^{3}$ Averaged over the 2 yr of study (2002 and 2003).

${ }^{4} \mathrm{TNC}=$ Total nonstructural carbohydrates.

${ }^{5}$ IVDMD = In vitro DM disappearance.

split in 2 equal feedings after milking (Table 1). An upper limit of $9.2 \mathrm{~kg}$ of DM/d per cow was established to minimize the risk of metabolic problems in the rumen. Any concentrate orts were removed and weighed after each feeding. The total diet consisted of $40 \%$ concentrate and $60 \%$ forage in 2002 , and $47 \%$ concentrate and $53 \%$ forage in 2003 , with $100 \%$ of the forage coming from pasture both years.

Measurement of pregrazing herbage mass and botanical composition were described previously (Sanderson et al., 2005). In brief, 30 readings were taken in each pasture with a calibrated rising-plate meter (Jenn Quip model, Feilding, New Zealand) twice each week. A single calibration equation was developed for all forage mixtures within each year. The calibration equation for 2002 was herbage mass $(\mathrm{kg} / \mathrm{ha}$ of $\mathrm{DM})=$ $353+84.5 \times$ (rising plate reading), $\mathrm{r}^{2}=0.82$, root error mean square $=318 \mathrm{~kg} / \mathrm{ha}$ of $\mathrm{DM}, \mathrm{n}=78$. The equation for 2003 was herbage mass $=-30+90.6 \times($ rising plate reading), $r^{2}=0.85$, root error mean square $=295 \mathrm{~kg} /$ ha of DM, $n=80$. Botanical composition was measured during 2 consecutive weeks before the start of the first intake period and during 2 consecutive weeks of each 
of the 4 intake periods. At each sampling, herbage in ten $0.03-\mathrm{m}^{2}$ quadrats was hand-clipped to a $1-\mathrm{cm}$ stubble height in each pasture and bulked. The bulked herbage was hand separated into dead material, sown forage species, and weeds (unsown species), dried at $55^{\circ} \mathrm{C}$ for $48 \mathrm{~h}$, and weighed. Data are averages across all sampling weeks for each grazing season. Pregrazing herbage mass was used to adjust paddock size based on herbage yield. Cows were allotted $25 \mathrm{~kg} / \mathrm{d}$ of DM per cow of herbage mass. Using temporary polywire, new paddocks were constructed daily. Daily paddocks were subdivided and back-fenced so that cows were offered fresh pasture ( $1 / 2$ of the daily herbage allowance) after each milking. During slower periods of pasture growth, pastures were rested for $7 \mathrm{~d}$ in mid-June each year (between periods 2 and 3) before resuming the trial. During this pasture recovery period, cows were kept on pastures that contained the same forages as the experimental pastures.

Cows were milked at 0500 and $1700 \mathrm{~h}$ and received bST injections every $2 \mathrm{wk}$. Walking distance from the pasture to the milking parlor averaged $0.9 \mathrm{~km}$ (range: 0.75 to $1.2 \mathrm{~km}$ ); therefore, cows walked an average of $3.6 \mathrm{~km} / \mathrm{d}$.

\section{Experimental Measures and Sample Analyses}

Total DMI was estimated using $\mathrm{Cr}_{2} \mathrm{O}_{3}$ as an indigestible fecal marker during wk 3 of each of the 4 experimental periods (Holden et al., 1994). Beginning on d 8 of each period and continuing for $11 \mathrm{~d}, \mathrm{Cr}_{2} \mathrm{O}_{3}$ was administered twice daily $(10 \mathrm{~g} / \mathrm{d})$ after each milking (0600 and $1800 \mathrm{~h}$ ) via gelatin capsules. Fecal grab samples were collected at 0600 and $1800 \mathrm{~h}$ on d 15 to 19 of each period and immediately frozen $\left(-20^{\circ} \mathrm{C}\right)$.

On d 14 to 18 of each period, samples of concentrate were collected for nutritional analyses. Pasture samples were plucked by hand to approximate the height at which the cows grazed to be used to determine forage quality during the intake period. Hand-plucked pasture samples were also taken once weekly throughout the grazing season to monitor forage quality. Concentrate samples were taken once weekly. Samples were dried at $55^{\circ} \mathrm{C}$ in a forced air oven for $48 \mathrm{~h}$ and ground through a 1-mm screen (Wiley mill, Thomas Scientific, Philadelphia, PA). Weekly concentrate and daily hand-plucked pasture samples (intake period) were composited by period. Weekly hand-plucked pasture samples were kept as weekly samples. Concentrate and pasture samples were analyzed for DM, CP, ash (AOAC, 1990), soluble CP (Roe et al., 1990), ADF, and NDF (ANKOM ${ }^{200}$ Fiber Analyzer, Ankom Technology Corp., Fairport, NY), nonstructural carbohydrates (NSC; Smith, 1981, modified to use potassium ferricy- anide as the colorimetric indicator), and in vitro DM disappearance (IVDMD) by a 2 -stage procedure (Tilley and Terry, 1963). Concentrate and pasture samples were analyzed for mineral content by wet chemistry (Dairy One Forage Analysis Laboratory, Ithaca, NY).

Fecal samples were thawed, dried at $55^{\circ} \mathrm{C}$ in a forced air oven for $96 \mathrm{~h}$, and ground through a 1-mm screen (Wiley mill). A composited sample per cow was made for each period (by year) for fecal output estimates. Fecal samples were analyzed for CP (AOAC, 1990), NDF (Ankom ${ }^{200}$ Fiber Analyzer, Ankom Technology Corp.), and Cr (Parker et al., 1989).

Intake was estimated using the equation DMI = fecal output/(1 - IVDMD). Fecal output was estimated using the equation fecal output $=(\mathrm{g}$ of $\mathrm{Cr}$ dosed per $\mathrm{d}) /(\mathrm{g}$ of $\mathrm{Cr} / \mathrm{g}$ of fecal DM). Pasture DMI was estimated by difference between the estimated total DMI (based on fecal output) and the known concentrate DMI. The proportionate IVDMD (using known concentrate DMI and estimated pasture DMI) of the pasture and the concentrate were used to determine total DMI (Holden et al., 1994).

Milk production was recorded daily. Milk samples were collected twice weekly during wk 2 and 3 of each period and preserved with 2-bromo-2-nitroproprane1,3 diol. Milk fat and protein, lactose, and MUN were analyzed by infrared spectrophotometry (Foss 605B MilkoScan, Foss Electric, Hillerød, Denmark; AOAC, 1990) by the Pennsylvania DHIA laboratory. Milk fatty acids (FA) were extracted and subsequently transmethylated as described by Baumgard et al. (2002). Fatty acid methyl esters were quantified by gas chromatography (Hewlett Packard 6890, Foster City, CA. Separations were made with the SP 2560 fused silica capillary column (Supelco, Bellefonte, PA). The column was $100 \mathrm{~m}$ in length, with an inner diameter of $0.25 \mathrm{~mm}$ and a film thickness of $0.2 \mu \mathrm{m}$. Oven temperatures were initially set at $80^{\circ} \mathrm{C}$ and held for $15 \mathrm{~min}$. Helium was the carrier gas and flowed at 1.1 $\mathrm{mL} / \mathrm{min}(17 \mathrm{~cm} / \mathrm{s}$, velocity). Airflow was set at $400 \mathrm{~mL} /$ min and the makeup gas, hydrogen, was $45 \mathrm{~mL} / \mathrm{min}$. Inlet and detector temperatures were set at $250^{\circ} \mathrm{C}$. Retention times were determined with pure methyl ester standards (Nu-Chek Prep, Elysian, MN; GLC60, cis-9, trans-11 conjugated linoleic acid (CLA) and trans-10, cis-12 CLA). A butter oil reference standard (CRM 164; Commission of the European Community Bureau of References, Brussels, Belgium) was used to determine the efficiencies of recoveries and correction factors for individual FA as described by Baumgard et al. (2002). Molar basis FA production $(\mathrm{mmol} / \mathrm{d})$ was estimated by dividing the yield (on a mass basis) by the molecular weight of each individual FA as described by Peterson et al. (2002). Additionally, milk samples were 
collected approximately 2 wk before and 2 wk after the experiment (all cows were consuming the same TMR in confinement during both periods) and analyzed for milk FA content for comparison.

Twice weekly, at $0600 \mathrm{~h}$, during wk 2 and 3 of each period before cows received concentrate, blood samples were collected from the coccygeal vein into one $20-\mathrm{mL}$ evacuated tube containing sodium heparin, and one 10-mL evacuated tube containing potassium oxylatesodium fluoride (glycolytic inhibitor). Blood was immediately placed on ice and transported to the laboratory. Samples were centrifuged at $3,000 \times g$ for $15 \mathrm{~min}$ at $4^{\circ} \mathrm{C}$. Heparinized plasma was analyzed for urea $\mathrm{N}$ (Stanbio Urea Nitrogen kit 580, Stanbio Laboratory, Inc., San Antonio, TX) and NEFA (NEFA C-kit no. 990-75401, Wako Chemicals USA, Inc., Richmond, VA) concentrations. Nonheparinized plasma was analyzed for glucose (Glucose kit no. 510, Sigma Chemical Co., St. Louis, MO) concentration.

Urine samples were taken by vulval stimulation twice daily after each milking on 2 consecutive days in wk 3 of each period. Samples were acidified with $\mathrm{HCl}$ to maintain a $\mathrm{pH}$ below 2 and stored at $-20^{\circ} \mathrm{C}$. Urine samples were later thawed, composited to one sample per period per cow, and analyzed for allantoin (Chen, 1989) and creatinine (Sigma kit no. 555-a) to estimate microbial protein synthesis in the rumen (Gonda, 1995).

\section{Statistical Analyses}

Animal performance data were analyzed using the PROC MIXED procedure of SAS (Littell et al., 1996). The model included the fixed effects of treatment (forage mixture), week, period, year, cow block, treatment $\times$ year, and treatment $\times$ period interactions, the random effect of cow nested within treatment (except pasture analyses), and the residual error. For each animal variable analyzed, cow nested within treatment was subjected to 3 covariance structures in PROC MIXED: unstructured, compound symmetry, and autoregressive order 1 covariance. The covariance structure that resulted in the smallest Akaike's information criterion and Schwarz Bayesian criterion was used.

Forage yield data were analyzed as a randomized complete block design with the PROC MIXED procedure of SAS mixed models procedure in SAS (Littell et al., 1996). Treatments were considered fixed effects and blocks were random. Years were analyzed separately.

Least squares means and SEM are reported for all data. Nonsignificant interactions were not reported. When significant $(P<0.05)$ effects due to dietary treat- ment, period, year, or any interaction were detected, mean separation was conducted by the PDIFF option in SAS (SAS Institute, 1999).

\section{RESULTS}

\section{Pasture Management and Forage Quality}

Pasture forage quality averaged $23.0 \% \mathrm{CP}, 18.6 \%$ total NSC, $22.1 \% \mathrm{ADF}, 32.3 \% \mathrm{NDF}$, and $64.1 \%$ IVDMD across forage mixtures and years (Table 2). The average pregrazing botanical composition of the 2SP mixture remained about the same in both years with 32 to $38 \%$ legume, 43 to $49 \%$ orchardgrass, and 21 to $13 \%$ weed from 2002 to 2003 (Sanderson et al., 2005; Table 3 ). The 3SP mixture changed from 25 to $52 \%$ legume, 18 to $25 \%$ grass, 34 to $16 \%$ chicory, and 23 to $6 \%$ weed for 2002 and 2003, respectively. The 6SP mixture changed from 28 to $24 \%$ legume, 23 to $42 \%$ grass, 35 to $25 \%$ chicory, and $10 \%$ weed for 2002 and 2003 , respectively. The 9SP mixture changed from 44 to $65 \%$ legume, $12 \%$ grass, 39 to $19 \%$ chicory, and $4 \%$ weed for 2002 and 2003, respectively. Chicory decreased in each mixture, whereas the orchardgrass and legume proportions increased from 2002 to 2003.

\section{DM and Nutrient Intake}

Dry matter intake was not affected $(P>0.05)$ by forage mixture; however, there was a significant $(P$ $<0.05$ ) year effect for pasture DMI and total DMI expressed as kilograms per day and as a percentage of BW (Table 4). Pasture DMI for all forage mixtures was slightly higher during 2002 than in 2003.

\section{Milk Production and Composition}

Milk production and $4 \%$ FCM were not affected ( $P$ $>0.05$ ) by forage mixture or by year (Table 5). Forage mixture did not affect $(P>0.05) 4 \%$ FCM, milk fat percentage, milk protein percentage, MUN, or lactose (Table 5). There was a significant period effect $(P<$ 0.05) for FCM, milk fat yield, and MUN.

\section{Milk Fatty Acids}

The FA composition of milk for the pretrial, experimental, and posttrial periods is shown in Table 6 . Short- and medium-chain fatty acids were not affected by forage mixture during the experimental period $(P>$ $0.05)$. Milk from cows grazing the 2SP pasture mixture had lower $(P<0.05)$ C18:2 and CLA content than the 
Table 2. Chemical composition of the hand-plucked pasture samples for 4 forage mixtures (averaged across all periods; DM basis)

\begin{tabular}{|c|c|c|c|c|c|c|}
\hline & \multicolumn{4}{|c|}{ Forage mixture $^{1}$} & \multirow[b]{2}{*}{ Mean } & \multirow[b]{2}{*}{ SEM } \\
\hline & $2 \mathrm{SP}$ & $3 \mathrm{SP}$ & $6 \mathrm{SP}$ & 9SP & & \\
\hline \multicolumn{7}{|l|}{$\mathrm{DM}, \%$} \\
\hline 2002 & $18.4^{\mathrm{a}}$ & $17.2^{\mathrm{ab}}$ & $17.0^{\mathrm{ab}}$ & $16.0^{\mathrm{b}}$ & 17.2 & 1.0 \\
\hline 2003 & 19.5 & 17.9 & 18.1 & 18.7 & 18.6 & 1.0 \\
\hline \multicolumn{7}{|c|}{$\mathrm{OM}, \%$ of $\mathrm{DM}$} \\
\hline 2002 & $90.4^{\mathrm{a}}$ & $89.5^{b}$ & $89.4^{b}$ & $89.2^{\mathrm{b}}$ & 89.6 & 0.2 \\
\hline 2003 & $89.9^{\mathrm{a}}$ & $89.0^{\mathrm{b}}$ & $89.1^{\mathrm{b}}$ & $88.8^{\mathrm{b}}$ & 89.2 & 0.2 \\
\hline \multicolumn{7}{|c|}{$\mathrm{CP}, \%$ of $\mathrm{DM}$} \\
\hline 2002 & $21.8^{\mathrm{a}}$ & $20.0^{\mathrm{b}}$ & $21.2^{\mathrm{ab}}$ & $22.5^{\mathrm{a}}$ & 21.4 & 0.5 \\
\hline 2003 & $23.2^{\mathrm{b}}$ & $24.6^{\mathrm{ab}}$ & $24.1^{\mathrm{b}}$ & $25.9^{\mathrm{a}}$ & 24.5 & 0.5 \\
\hline \multicolumn{7}{|c|}{ Soluble CP, $\%$ of DM } \\
\hline 2002 & 6.1 & 6.8 & 6.6 & 6.1 & 6.4 & 0.4 \\
\hline 2003 & $7.5^{\mathrm{bc}}$ & $8.0^{\mathrm{ab}}$ & $7.1^{\mathrm{c}}$ & $8.5^{\mathrm{a}}$ & 7.8 & 0.4 \\
\hline \multicolumn{7}{|c|}{$\mathrm{TNC}^{2} \%$ of $\mathrm{DM}$} \\
\hline 2002 & $18.4^{b}$ & $20.9^{\mathrm{a}}$ & $21.5^{\mathrm{a}}$ & $21.7^{\mathrm{a}}$ & 20.6 & 0.7 \\
\hline 2003 & $15.2^{\mathrm{b}}$ & $16.9^{\mathrm{ab}}$ & $18.3^{\mathrm{a}}$ & $16.2^{\mathrm{b}}$ & 16.7 & 0.7 \\
\hline \multicolumn{7}{|c|}{$\mathrm{NDF}, \%$ of DM } \\
\hline 2002 & $36.6^{\mathrm{a}}$ & $31.6^{\mathrm{b}}$ & $29.3^{\mathrm{b}}$ & $24.5^{\mathrm{c}}$ & 30.5 & 1.5 \\
\hline 2003 & $40.8^{\mathrm{a}}$ & $31.8^{\mathrm{b}}$ & $35.4^{\mathrm{b}}$ & $28.2^{\mathrm{b}}$ & 34.1 & 1.5 \\
\hline \multicolumn{7}{|c|}{$\mathrm{ADF}, \%$ of $\mathrm{DM}$} \\
\hline 2002 & $23.2^{\mathrm{a}}$ & $22.0^{\mathrm{a}}$ & $20.5^{\mathrm{ac}}$ & $18.8^{\mathrm{bc}}$ & 21.1 & 0.8 \\
\hline 2003 & $25.2^{\mathrm{a}}$ & $22.7^{\mathrm{b}}$ & $22.8^{\mathrm{b}}$ & $21.8^{\mathrm{b}}$ & 23.1 & 0.8 \\
\hline \multicolumn{7}{|c|}{ IVDMD ${ }^{3} \%$ of DM } \\
\hline 2002 & $66.6^{\mathrm{c}}$ & $70.4^{\mathrm{ab}}$ & $67.2^{\mathrm{bc}}$ & $70.9^{\mathrm{a}}$ & 68.8 & 1.2 \\
\hline 2003 & $58.4^{\mathrm{bc}}$ & $60.6^{\mathrm{ab}}$ & $57.2^{\mathrm{c}}$ & $61.0^{\mathrm{a}}$ & 59.3 & 1.2 \\
\hline \multicolumn{7}{|c|}{$\mathrm{Ca}, \%$ of $\mathrm{DM}$} \\
\hline 2002 & $1.00^{\mathrm{b}}$ & $1.25^{\mathrm{b}}$ & $1.37^{\mathrm{a}}$ & $1.38^{\mathrm{a}}$ & 1.25 & 0.03 \\
\hline 2003 & $0.94^{\mathrm{d}}$ & $1.30^{\mathrm{b}}$ & $1.12^{\mathrm{c}}$ & $1.44^{\mathrm{a}}$ & 1.20 & 0.03 \\
\hline \multicolumn{7}{|c|}{$\mathrm{P}, \%$ of $\mathrm{DM}$} \\
\hline 2002 & $0.42^{\mathrm{c}}$ & $0.54^{\mathrm{a}}$ & $0.50^{\mathrm{b}}$ & $0.49^{b}$ & 0.49 & 0.01 \\
\hline 2003 & 0.47 & 0.49 & 0.46 & 0.49 & 0.48 & 0.01 \\
\hline \multicolumn{7}{|c|}{$\mathrm{Mg}, \%$ of $\mathrm{DM}$} \\
\hline 2002 & $0.25^{\mathrm{b}}$ & $0.27^{\mathrm{b}}$ & $0.31^{\mathrm{ab}}$ & $0.28^{\mathrm{ab}}$ & 0.28 & 0.01 \\
\hline 2003 & $0.26^{\mathrm{b}}$ & $0.28^{\mathrm{ab}}$ & $0.30^{\mathrm{a}}$ & $0.29^{\mathrm{ab}}$ & 0.28 & 0.01 \\
\hline \multicolumn{7}{|c|}{$\mathrm{K}, \%$ of $\mathrm{DM}$} \\
\hline 2002 & $3.17^{\mathrm{c}}$ & $3.83^{\mathrm{a}}$ & $3.65^{\mathrm{b}}$ & $3.68^{\mathrm{b}}$ & 3.58 & 0.04 \\
\hline 2003 & $3.40^{\mathrm{c}}$ & $3.54^{\mathrm{b}}$ & $3.60^{\mathrm{b}}$ & $3.70^{\mathrm{a}}$ & 3.56 & 0.04 \\
\hline \multicolumn{7}{|c|}{$\mathrm{Na}, \%$ of $\mathrm{DM}$} \\
\hline 2002 & $0.020^{\mathrm{c}}$ & $0.036^{\mathrm{b}}$ & $0.054^{\mathrm{a}}$ & $0.040^{\mathrm{b}}$ & 0.038 & 0.002 \\
\hline 2003 & $0.015^{\mathrm{c}}$ & $0.035^{\mathrm{a}}$ & $0.039^{\mathrm{a}}$ & $0.028^{\mathrm{b}}$ & 0.029 & 0.002 \\
\hline \multicolumn{7}{|c|}{$\mathrm{S}, \%$ of $\mathrm{DM}$} \\
\hline 2002 & $0.30^{\mathrm{c}}$ & $0.35^{\mathrm{b}}$ & $0.36^{\mathrm{b}}$ & $0.41^{\mathrm{a}}$ & 0.36 & 0.01 \\
\hline 2003 & $0.30^{\mathrm{ab}}$ & $0.31^{\mathrm{ab}}$ & $0.33^{\mathrm{a}}$ & $0.29^{\mathrm{b}}$ & 0.31 & 0.01 \\
\hline
\end{tabular}

${ }^{a-d}$ Means within the same row (within year) with different superscripts differ $(P<0.05)$.

${ }^{1} 2 \mathrm{SP}=$ Orchardgrass and white clover; $3 \mathrm{SP}=$ orchardgrass, white clover, and chicory; $6 \mathrm{SP}=$ orchardgrass, tall fescue, perennial ryegrass, red clover, birdsfoot trefoil, and chicory; 9SP $=6 \mathrm{SP}$ mixture plus white clover, alfalfa, and Kentucky bluegrass.

${ }^{2} \mathrm{TNC}=$ Total nonstructural carbohydrates.

${ }^{3}$ IVDMD $=$ In vitro DM disappearance.

more complex mixtures. No other long-chain fatty acids were affected by forage mixture $(P>0.05)$. The CLA and C18:3 content were lower $(P<0.05)$ during the pre- and posttrial periods than during the experimental periods.

\section{Plasma and Urine Metabolites}

Plasma glucose, plasma urea nitrogen, and NEFA concentrations were not affected $(P>0.05)$ by forage mixture (Table 7). Plasma glucose concentration was not affected $(P>0.05)$ by year; however, year had a significant effect $(P<0.05)$ on plasma urea nitrogen and NEFA concentrations. Urinary allantoin concentrations were lower $(P<0.05)$ in the 9SP mixture in 2002 , and higher $(P<0.05)$ in the 2SP mixture in 2003 than the other mixtures. Creatinine concentrations were higher $(P<0.05)$ in the 2SP mixture only in 2003. The allantoin/creatinine ratio was not affected $(P>$ 0.05 ) by forage mixture or year. 
Table 3. Pregrazing botanical composition of 4 forage mixtures over 2 grazing seasons (2002 and 2003; mean for the grazing season within each year)

\begin{tabular}{|c|c|c|c|c|c|c|c|c|c|c|}
\hline $\begin{array}{l}\text { Forage } \\
\text { mixture }^{1}\end{array}$ & $\begin{array}{l}\text { White } \\
\text { clover }\end{array}$ & $\begin{array}{l}\text { Orchard- } \\
\text { grass }\end{array}$ & Chicory & $\begin{array}{l}\text { Red } \\
\text { clover }\end{array}$ & $\begin{array}{l}\text { Tall } \\
\text { fescue }\end{array}$ & $\begin{array}{l}\text { Birdsfoot } \\
\text { trefoil }\end{array}$ & Alfalfa & $\begin{array}{l}\text { Blue- } \\
\text { grass }\end{array}$ & $\begin{array}{l}\text { Perennial } \\
\text { ryegrass }\end{array}$ & Weeds \\
\hline & & & & $-\mathrm{P}$ & rcentage & of green D & $\mathrm{M}$ & 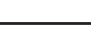 & 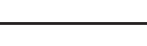 & 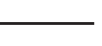 \\
\hline \multicolumn{11}{|l|}{2002} \\
\hline $2 \mathrm{SP}$ & 32.0 & 42.6 & - & - & - & - & - & - & - & 21.4 \\
\hline $3 \mathrm{SP}$ & 25.3 & 17.5 & 33.6 & - & - & - & - & - & - & 22.9 \\
\hline $6 \mathrm{SP}$ & - & 18.2 & 34.6 & 25.8 & 4.8 & 2.0 & - & 0.2 & - & 11.5 \\
\hline 9SP & 20.1 & 4.2 & 39.1 & 19.5 & 3.3 & 0.5 & 3.8 & 0.5 & 4.0 & 4.9 \\
\hline \multicolumn{11}{|l|}{2003} \\
\hline 2SP & 38.3 & 48.9 & - & - & - & - & - & - & - & 12.8 \\
\hline 3SP & 51.9 & 25.3 & 16.5 & - & - & - & - & - & - & 6.4 \\
\hline $6 \mathrm{SP}$ & - & 37.6 & 24.8 & 21.8 & 4.0 & 2.0 & - & 0.1 & - & 9.7 \\
\hline 9SP & 53.5 & 10.1 & 18.9 & 9.1 & 1.3 & 0.6 & 1.6 & 0.2 & 1.8 & 2.9 \\
\hline
\end{tabular}

${ }^{1} 2 \mathrm{SP}=$ Orchardgrass and white clover; $3 \mathrm{SP}=$ orchardgrass, white clover, and chicory; $6 \mathrm{SP}=$ orchardgrass, tall fescue, perennial ryegrass, red clover, birdsfoot trefoil, and chicory; 9SP $=6 \mathrm{SP}$ mixture plus white clover, alfalfa, and Kentucky bluegrass.

\section{DISCUSSION}

\section{Pasture Management and Forage Quality}

Forage quality was within the range summarized by Muller and Fales (1998) for cool-season forages in Pennsylvania. The IVDMD was higher than that reported by others (Kolver et al., 1998; Bargo et al., 2002b). Barry (1998) reported that chicory had a higher apparent OM digestibility (82\%) when compared with perennial ryegrass $(74 \%)$. The NSC content and mineral content were generally higher for the 3SP, 6SP, and 9SP mixtures than the 2SP mixture, probably due to the presence of chicory. Chicory has a greater mineral and NSC content than do cool-season grasses (Barry, 1998).

Total seasonal (April to October) herbage yields were $4,800,7,400,7,900$, and $7,500 \mathrm{~kg}$ of DM/ha in 2002 for the 2SP, 3SP, 6SP, and 9SP mixtures, respectively (Sanderson et al., 2005). The 2SP mixture yielded less than the 3SP, 6SP, and 9SP mixtures, which did not differ from each other in yield. Total seasonal herbage yields in 2003 averaged $9,900 \mathrm{~kg}$ of $\mathrm{DM} /$ ha with no differences among mixtures (Sanderson et al., 2005). Herbage yield was lower in 2002 than in 2003 due to lower rainfall (46\% below average) and higher temperatures $\left(1^{\circ} \mathrm{C}\right.$ above average $)$ in the

Table 4. Dry matter and nutrient intake of dairy cows grazing 4 forage mixtures over 2 grazing seasons (2002 and 2003)

\begin{tabular}{|c|c|c|c|c|c|c|}
\hline & \multicolumn{4}{|c|}{ Forage mixture $^{1}$} & \multirow[b]{2}{*}{ SEM } & \multirow[b]{2}{*}{$P$-value } \\
\hline & 2SP & $3 \mathrm{SP}$ & $6 \mathrm{SP}$ & 9SP & & \\
\hline \multicolumn{7}{|c|}{ Pasture DMI, ${ }^{2,3} \mathrm{~kg} / \mathrm{d}$} \\
\hline 2002 & 13.7 & 13.7 & 13.6 & 12.9 & 0.40 & 0.25 \\
\hline 2003 & 11.1 & 10.5 & 10.5 & 10.2 & 0.40 & 0.25 \\
\hline \multicolumn{7}{|c|}{ Supplement DMI, kg/d } \\
\hline 2002 & 9.2 & 9.2 & 9.2 & 9.2 & $<0.1$ & - \\
\hline 2003 & 9.2 & 9.2 & 9.2 & 9.2 & $<0.1$ & - \\
\hline \multicolumn{7}{|c|}{ Total DMI, kg/d ${ }^{3}$} \\
\hline 2002 & 22.9 & 22.9 & 22.8 & 22.1 & 0.5 & 0.36 \\
\hline 2003 & 20.3 & 19.7 & 19.7 & 19.4 & 0.5 & 0.36 \\
\hline \multicolumn{7}{|c|}{ Total DMI, \% of BW ${ }^{4}$} \\
\hline 2002 & 3.68 & 3.61 & 3.63 & 3.51 & 0.11 & 0.27 \\
\hline 2003 & 3.20 & 3.08 & 3.10 & 3.04 & 0.11 & 0.27 \\
\hline
\end{tabular}

${ }^{\mathrm{a}, \mathrm{b}}$ Means within the same row with different superscripts $\operatorname{differ}(P<0.05)$.

${ }_{1}^{1} \mathrm{SP}=$ Orchardgrass and white clover; $3 \mathrm{SP}=$ orchardgrass, white clover, and chicory; $6 \mathrm{SP}=$ orchardgrass, tall fescue, perennial ryegrass, red clover, birdsfoot trefoil, and chicory; 9SP $=6 \mathrm{SP}$ mixture plus white clover, alfalfa, and Kentucky bluegrass.

${ }^{2}$ Estimated using $\mathrm{Cr}_{2} \mathrm{O}_{3}$.

${ }^{3}$ Significant year effect $(P<0.05)$.

${ }^{4}$ BW: $648 \pm 74 \mathrm{~kg}$. 
Table 5. Milk yield and composition of dairy cows grazing 4 forage mixtures over 2 grazing seasons (2002 and 2003; averaged across the 2 yr unless otherwise noted)

\begin{tabular}{|c|c|c|c|c|c|c|}
\hline & \multicolumn{4}{|c|}{ Forage mixture $^{1}$} & \multirow[b]{2}{*}{ SEM } & \multirow[b]{2}{*}{$P$-value } \\
\hline & $2 \mathrm{SP}$ & $3 \mathrm{SP}$ & $6 \mathrm{SP}$ & 9SP & & \\
\hline Milk, kg/d & 33.9 & 35.4 & 34.4 & 34.3 & 1.3 & 0.87 \\
\hline Milk fat, \% & 3.5 & 3.4 & 3.5 & 3.3 & 0.12 & 0.53 \\
\hline $4 \%$ FCM, $\mathrm{kg} / \mathrm{d}$ & 30.1 & 31.1 & 30.7 & 30.1 & 1.6 & 0.91 \\
\hline True protein, \% & 2.80 & 2.82 & 2.79 & 2.81 & 0.04 & 0.84 \\
\hline Lactose, $\%$ & 4.63 & 4.63 & 4.62 & 4.63 & 0.09 & 0.99 \\
\hline \multicolumn{7}{|l|}{ MUN, mg/dL ${ }^{2}$} \\
\hline 2002 & 12.4 & 11.1 & 12.3 & 12.5 & 0.3 & 0.08 \\
\hline 2003 & 14.5 & 15.2 & 13.4 & 15.0 & 0.3 & 0.08 \\
\hline
\end{tabular}

${ }^{1} 2 \mathrm{SP}=$ Orchardgrass and white clover; $3 \mathrm{SP}=$ orchardgrass, white clover, and chicory; $6 \mathrm{SP}=$ orchardgrass, tall fescue, perennial ryegrass, red clover, birdsfoot trefoil, and chicory; 9SP = 6SP mixture plus white clover, alfalfa, and Kentucky bluegrass.

${ }^{2}$ Significant year effect $(P<0.05)$.

summer of 2002 compared with 2003, which had 59\% above-average rainfall and $2.5^{\circ} \mathrm{C}$ below average summer temperatures.

The proportion of chicory in the herbage of the 3SP, 6SP, and 9SP mixtures was higher in the postgrazing residue than in the pregrazing herbage (Sanderson et al., 2005). This suggests that cattle preferred the grasses and legumes and partly avoided the chicory. Chicory contains sesquiterpene lactones, which impart a bitter taste to the herbage and may deter animal grazing (Foster et al., 2002). There may have also been selective grazing of the chicory, as the grazing season progressed and the chicory began to bolt, the cattle appeared to favor the young leaf growth of the chicory while avoiding the mature leaves and bolting stem, which would have been left in the postgrazing samples.

\section{DM and Nutrient Intake}

Dry matter intake was slightly lower during 2003 than in 2002, partly a result of higher NDF and lower IVDMD in 2003. Variation associated with the $\mathrm{Cr}_{2} \mathrm{O}_{3}$

Table 6. Fatty acid (FA) profile in milk fat of dairy cows grazing 4 forage mixtures over 2 grazing seasons (2002 and 2003)

\begin{tabular}{|c|c|c|c|c|c|c|c|}
\hline \multirow[b]{2}{*}{ FA, g/100 $\mathrm{g}$ of FA } & \multirow{2}{*}{$\frac{\text { Pretrial period }}{\text { Mean }( \pm \mathrm{SD})^{1}}$} & \multicolumn{4}{|c|}{ Forage mixture ${ }^{2}$} & \multirow[b]{2}{*}{ SEM } & \multirow{2}{*}{$\frac{\text { Posttrial period }}{\text { Mean }( \pm \mathrm{SD})^{3}}$} \\
\hline & & $2 \mathrm{SP}$ & $3 \mathrm{SP}$ & $6 \mathrm{SP}$ & 9SP & & \\
\hline $\mathrm{C} 4: 0$ & $3.11 \pm 0.72$ & 2.75 & 2.83 & 2.92 & 2.82 & 0.21 & $3.95 \pm 1.99$ \\
\hline C6:0 & $2.41 \pm 0.44$ & 2.20 & 2.14 & 2.22 & 2.09 & 0.10 & $2.76 \pm 1.33$ \\
\hline C8:0 & $1.36 \pm 0.23$ & 1.25 & 1.24 & 1.22 & 1.21 & 0.05 & $1.44 \pm 0.43$ \\
\hline C10:0 & $2.83 \pm 0.61$ & 2.45 & 2.49 & 2.44 & 2.44 & 0.08 & $2.68 \pm 0.52$ \\
\hline C12:0 & $2.96 \pm 0.65$ & 2.55 & 2.53 & 2.44 & 2.51 & 0.07 & $3.10 \pm 0.54$ \\
\hline Total short chain & $12.67 \pm 2.42$ & 11.06 & 11.22 & 11.21 & 11.08 & 0.39 & $13.72 \pm 3.59$ \\
\hline C14:0 & $9.32 \pm 1.56$ & 9.11 & & 9.07 & 8.85 & 0.16 & $9.87 \pm 1.42$ \\
\hline C14: & $0.68 \pm 0.19$ & 0.84 & 0.84 & 0.82 & 0.80 & 0.03 & $0.89 \pm 0.21$ \\
\hline C16:0 & $23.27 \pm 2.03$ & 24.75 & 25.35 & 24.61 & 24.41 & 0.53 & $29.20 \pm 4.49$ \\
\hline C16:1 & $1.20 \pm 0.37$ & 1.33 & 1.40 & 1.34 & 1.37 & 0.05 & $1.58 \pm 0.54$ \\
\hline Total medium chain & $35.17 \pm 2.99$ & 36.95 & 37.98 & 36.72 & 36.29 & 0.62 & $43.14 \pm 3.96$ \\
\hline C18:0 & $15.14 \pm 1.72$ & 14.13 & 13.67 & 14.29 & 13.04 & 0.35 & $11.57 \pm 2.74$ \\
\hline C18:1 & $28.89 \pm 3.53$ & 30.84 & 30.80 & 30.89 & 31.39 & 0.72 & $24.34 \pm 5.08$ \\
\hline C18:2 & $4.55 \pm 0.43$ & $4.06^{\mathrm{c}}$ & $4.69^{\mathrm{ab}}$ & $4.50^{\mathrm{b}}$ & $4.94^{\mathrm{a}}$ & 0.12 & $3.74 \pm 0.90$ \\
\hline CLA, cis-9, trans-11 & $0.52 \pm 0.09 *$ & $0.87^{\mathrm{b}}$ & $1.02^{\mathrm{a}}$ & $0.99^{\mathrm{a}}$ & $1.04^{\mathrm{a}}$ & 0.04 & $0.46 \pm 0.13^{*}$ \\
\hline C18:3 & $0.44 \pm 0.12^{*}$ & 1.06 & 0.99 & 1.03 & 0.94 & 0.05 & $0.64 \pm 0.16^{*}$ \\
\hline Total lo & $50.08 \pm 4.24$ & 51.64 & 51.88 & 52.35 & 52.01 & 0.76 & $41.60 \pm 6.32$ \\
\hline Saturated FA, $\%$ of total FA & $62 \pm 3.71$ & 61 & 61 & 61 & 59 & 1.26 & $67 \pm 4.50$ \\
\hline
\end{tabular}

${ }^{1}$ Pretrial samples were collected on April 15 (2002 and 2003) while cows were consuming a TMR (before transition to pasture).

${ }^{2}$ Samples were collected twice weekly from May 6 through August 3, 2002 (yr 1), and May 5 through August 2, 2003 (yr 2).

${ }^{3}$ Posttrial samples were collected on August 19 (2002 and 2003), 16 and 17 d (respectively) after cows were removed from pasture and placed back on a TMR.

*Significantly different from experimental periods $(P<0.05)$. 
Table 7. Blood and urine metabolites of dairy cows grazing 4 forage mixtures over 2 grazing seasons (2002 and 2003)

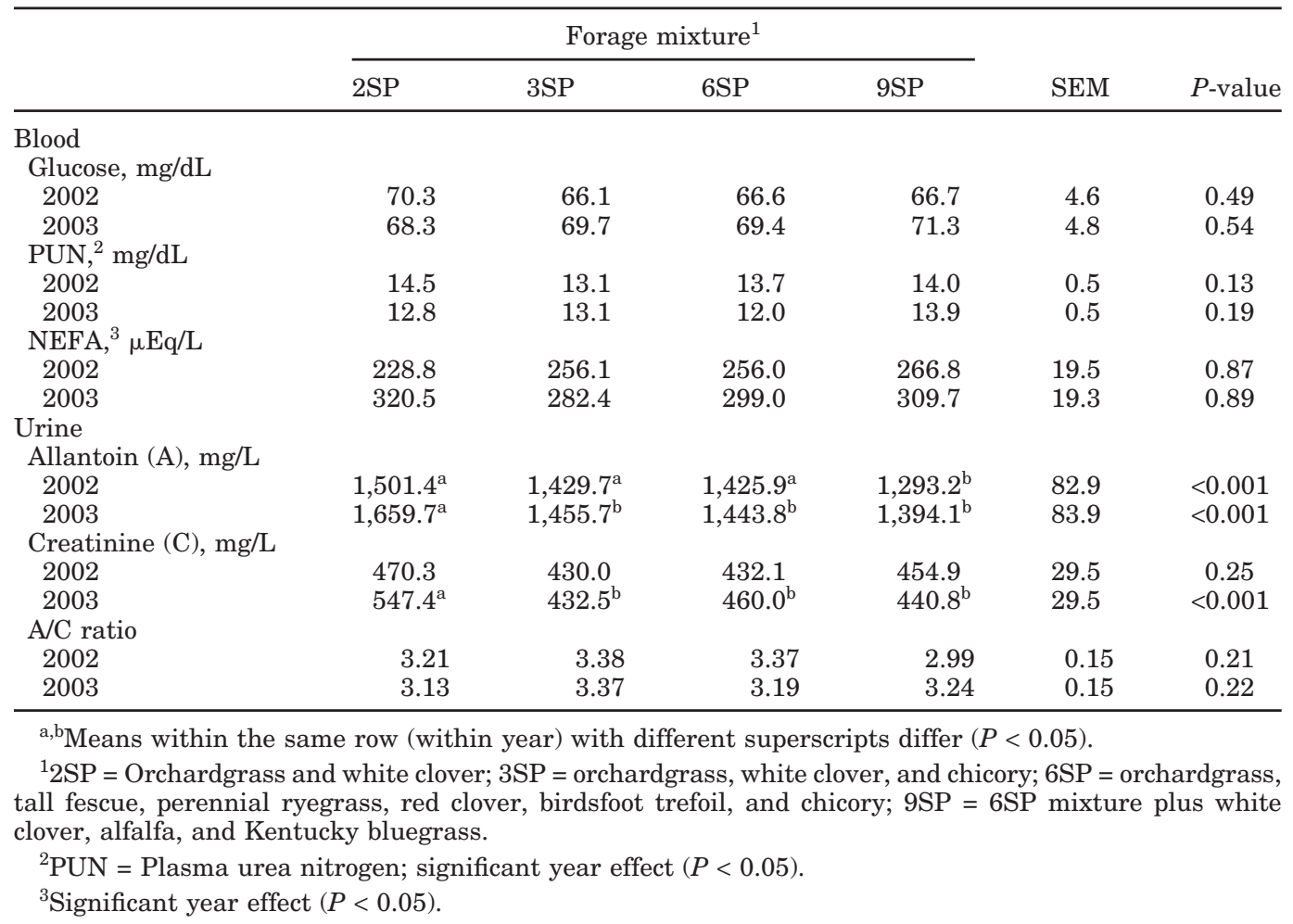

technique and use of different cows also contributed to year differences. Our pasture DMI values, however, were similar to those of others under similar experimental conditions (Holden et al., 1994; Bargo et al., 2002b). There was no effect of pasture species mixture on DMI of lactating dairy cows.

There have been few comparisons of herbage intake and milk production from forage mixtures on pasture, particularly in studies conducted in the United States. Others in Europe and New Zealand have reported improved herbage intake and milk production on grasslegume swards compared with grass monocultures (Harris et al., 1997; Phillips and James, 1998). Contrarily, Wedin et al. (1965) reported that complex forage mixtures supported less milk production than a simple grass-legume mixture or $\mathrm{N}$-fertilized grass. In our study, increasing mixture complexity by combining chicory and several species of grasses and legumes did not affect herbage intake or milk production. In addition, cows received $40 \%$ of their diet from a concentrate supplement, an economically beneficial practice due to milk to feed price ratios (Soder and Rotz, 2001). Supplementation may affect grazing behavior (Rook et al., 1994; Soriano et al., 2000), perhaps resulting in changes in grazing selection. Research is needed to determine if responses are the same for unsupple- mented vs. supplemented cows (or type of supplementation) for full lactation cycles.

\section{Milk Fatty Acids}

During the experimental grazing periods, milk CLA content was 188 and $213 \%$ higher than in the pre- and posttrial periods respectively (when cows were fed a TMR). Other studies showed that CLA content of milk increased between 150 to $500 \%$ when pasture was the primary source of forage in the diet of lactating dairy cows (Kelly et al., 1998; Dhiman et al., 1999; Schroeder et al., 2003). The increased CLA content in milk from cows grazing the 3SP, 6SP, and 9SP forage mixtures may have been a result of increased unsaturated FA content of the chicory ( 8 to $10 \mathrm{mg}$ of linoleic acid/g of $\mathrm{DM}, 30$ to $40 \mathrm{mg}$ of $\alpha$-linolenic acid/g of DM; W. Clapham, USDA-ARS, Beaver, WV; personal communication). Conversely, if the cows avoided grazing chicory, they may have consumed more legumes, which contain higher linoleic acid levels than cool-season grasses (Engelhart, 2003).

\section{Plasma and Urine Metabolites}

Plasma glucose, plasma urea nitrogen, and NEFA concentrations are within the ranges reported in other 
grazing studies using cows from the same research herd (Kolver and Muller, 1998; Bargo et al., 2002b). Other studies (Carruthers and Neil, 1997; Bargo et al., 2002b) reported similar values for allantoin concentrations (1,992 and $1,696 \mathrm{mg} / \mathrm{L}$, respectively) for grazing dairy cows supplemented with concentrate. The allantoin/creatinine ratio, an indirect indicator of ruminal microbial protein synthesis (Gonda, 1995) was not affected by species mixture or by weather conditions, suggesting that ruminal microbial protein synthesis was not altered by forage species mixture.

\section{CONCLUSIONS}

Forage mixture did not affect DMI, milk production, milk composition, or blood metabolites of high-producing cows. Although individual cow performance was not affected, our previous research demonstrated an herbage yield benefit for complex mixtures during a dry year and reduced weed invasion during establishment that may allow for increased stocking rates and greater milk production per hectare.

\section{ACKNOWLEDGMENTS}

The authors thank G. Varga and J. Heinrichs for use of laboratory space and equipment, and M. Rubano, K. Klement, J. Everhart, D. Genito, T. Cassidy, M. Long, C. Crawford, S. Ferguson, N. Brezezinski, W. Keyes, J. Zepp, D. Pighetti, C. Coiner, J. Delahoy, J. Homan, N. Houck, T. Edwards, and V. Ishler for assistance in conducting this trial.

\section{REFERENCES}

AOAC. Official Methods of Analysis. 1990. 15th ed. Association of Official Analytical Chemists, Washington, DC.

Bargo, F., L. D. Muller, J. Delahoy, and T. Cassidy. 2002a. Milk response to concentrate supplementation of high producing dairy cows grazing at two pasture allowances. J. Dairy Sci. 85:1777-1792.

Bargo, F., L. D. Muller, J. Delahoy, and T. Cassidy. 2002b. Performance of high producing dairy cows with three different feeding systems combining pasture and total mixed rations. J. Dairy Sci. 85:2948-2963.

Barry, T. N. 1998. The feeding value of chicory (Cichorium intybus) for ruminant livestock. J. Agric. Sci. (Camb.) 131:251-257.

Baumgard, L. H., D. Matitashvili, B. A. Corl, D. A. Dwyer, and D. E. Bauman. 2002. trans-10, cis-2 conjugated linoleic acid decreases lipogenic rates and expression of genes involved in milk lipid synthesis in dairy cows. J. Dairy Sci. 85:2155-2163.

Carruthers, V. R., and P. G. Neil. 1997. Milk production and ruminal metabolites from cows offered two pasture diets supplemented with non-structural carbohydrate. N.Z. J. Agric. Res. 40:513521.

Chen, X. B. 1989. Excretion of purine derivatives by sheep and cattle and its use for estimation of absorbed microbial protein. Ph.D. Diss., Swedish University of Agricultural Sciences, Uppsala.

Dalley, D. E., J. R. Roche, C. Grainger, and P. J. Moate. 1999. Dry matter intake, nutrient selection and milk production of dairy cows grazing rain-fed perennial pastures at different herbage allowances in spring. Aust. J. Exp. Agric. 39:923-931.
Deak, A., M. H. Hall, and M. A. Sanderson. 2004. Forage production and forage mixture complexity. Proc. Am. Forage Grassl. Conf. $13: 220-224$

Dhiman, T. R., G. R. Anand, L. D. Satter, and M. W. Pariza. 1999. Conjugated linoleic acid content of milk from cows fed different diets. J. Dairy Sci. 82:2146-2156.

Engelhart, E. M. 2003. Linoleic acid and linolenic acids in forage and their effect on grazing dairy cow performance and milk fatty acid composition. The Pennsylvania State University, University Park.

Fales, S. L., L. D. Muller, S. A. Ford, M. O'Sullivan, R. J. Hoover, L. A. Holden, L. E. Lanyon, and D. R. Buckmaster. 1995. Stocking rate affects production and profitability in a rotationally grazed pasture system. J. Prod. Agric. 8:88-96.

Foster, J. G., J. M. Fedders, W. M. Clapham, J. W. Robertson, D. P. Bligh, and K. E. Turner. 2002. Nutritive value and animal selection of forage chicory cultivars grown in central Appalachia. Agron. J. 94:1034-1042.

Ganskopp, D., B. Myers, S. Lambert, and R. Cruz. 1997. Preferences and behavior of cattle grazing eight varieties of grasses. J. Range Manage. 50:578-586.

Gonda, H. L. 1995. Nutritional status of ruminants determined from excretion and concentration of metabolites in body fluids. Ph.D. Diss. Swedish University of Agricultural Sciences, Department of Animal Nutrition and Management, Uppsala.

Harris, S. L., D. A. Clark, M. J. Auldist, C. D. Waugh, and P. G. Laboyrie. 1997. Optimum white clover content for dairy pastures. Proc. N.Z. Grassl. Assoc. 59:29-33.

Holden, L. A., L. D. Muller, and S. L. Fales. 1994. Estimation of intake in high producing Holstein cows grazing grass pasture. J. Dairy Sci. 77:2332-2340.

Kelly, M. L., E. S. Kolver, D. E. Bauman, M. E. Van Amburgh, and L. D. Muller. 1998. Effect of intake of pasture on concentrations of conjugated linoleic acid in milk of lactating cows. J. Dairy Sci. 81:1630-1636.

Kolver, E. S., and L. D. Muller. 1998. Performance and nutrient intake of high producing Holstein cows consuming pasture or a total mixed ration. J. Dairy Sci. 81:1403-1411.

Kolver, E. S., L. D. Muller, G. A. Varga, and T. W. Cassidy. 1998. Synchronization of ruminal degradation of supplemental carbohydrate with pasture nitrogen in lactating dairy cows. J. Dairy Sci. 81:2017-2028.

Littell, R. C., G. A. Milliken, W. W. Stroup, and R. D. Wolfinger. 1996. SAS system for mixed models. SAS Inst., Cary, NC.

Minns, A., J. Finn, A. Hector, M. Caldeira, J. Joshi, C. Palmborg, B. Schmid, M. Scherer-Lorenzen, E. Spehn, and A. Troubis. 2001. The functioning of European grassland ecosystems: Potential benefits of biodiversity to agriculture. Outlook Agric. 30:179185.

Muller, L. D., and S. L. Fales. 1998. Supplementation of cool-season grass pastures for dairy cattle. Pages 335-350 in Grass for dairy cattle. J. H. Cherney and D. J. R. Cherney, ed. CABI, New York, NY.

Parker, W. J., S. N. McCutcheon, and D. H. Carr. 1989. Effect of herbage type and level of intake on the release of chromic oxide from intraruminal controlled release capsules in sheep. N.Z. J. Agric. Res. 32:537-546.

Peterson, D. G., L. H. Baumgard, and D. E. Bauman. 2002. Milk fat response to low doses of trans-10, cis-12 conjugated linoleic acid (CLA). J. Dairy Sci. 85:1764-1766.

Phillips, C. J. C., and N. L. James. 1998. The effects of including white clover in perennial ryegrass swards and the height of mixed swards on the milk production, sward selection and ingestive behaviour of dairy cows. Anim. Sci. 67:195. (Abstr.)

Roe, M. B., C. J. Sniffen, and L. E. Chase. 1990. Techniques for measuring protein fractions in feedstuffs. Cornell Nutr. Conf. Feed Manuf. 52:81-88.

Rook, A. J., C. A. Huckle, and P. D. Penning. 1994. Effects of sward height and concentrate supplementation on the ingestive behavior of spring calving dairy cows grazing grass clover swards. Appl. Anim. Behav. Sci. 40:101-112. 
Rutter, S. M., R. J. Orr, N. H. Yarrow, and R. A. Champion. 2004. Dietary preference of dairy cows grazing ryegrass and white clover. J. Dairy Sci. 87:1317-1324.

Sanderson, M. A., K. J. Soder, L. D. Muller, K. D. Klement, R. H. Skinner, and S. C. Goslee. 2005. Forage mixture productivity and botanical composition in pastures grazed by dairy cattle. Agron. J. 97:1465-1471.

SAS Institute. 1999. SAS User's Guide. Statistics, Version 8.01 ed. SAS Inst. Inc., Cary, NC.

Schroeder, G. F., J. E. Delahoy, I. Vidaurreta, F. Bargo, G. A. Gagliostro, and L. D. Muller. 2003. Milk fatty acid composition of cows fed a total mixed ration or pasture plus concentrates replacing corn with fat. J. Dairy Sci. 86:3237-3248.

Smith, D. 1981. Removing and analyzing carbohydrates from plant tissue. Wisconsin Agric. Exp. Stn. Rep. R2107, Madison.
Soder, K. J., and C. A. Rotz. 2001. Economic and environmental impact of 4 levels of concentrate supplementation in grazing dairy herds. J. Dairy Sci. 84:2560-2572.

Soriano, F. D., C. E. Polan, and C. N. Miller. 2000. Milk production and composition, rumen fermentation parameters, and grazing behavior of dairy cows supplemented with different forms and amounts of grain. J. Dairy Sci. 83:1520-1529.

Tilley, J. M. A., and R. A. Terry. 1963. A two-stage technique for the in vitro digestion of forage crops. Br. Grassl. Soc. 18:104-111.

Tracy, B. F., and M. A. Sanderson. 2004. Forage productivity, species evenness and weed invasion in pasture communities. Agric. Ecosyst. Environ. 102:175-183.

Wedin, W. F., J. D. Donker, and G. C. Marten. 1965. An evaluation of nitrogen fertilization in legume-grass and all-grass pasture. Agron. J. 58:185-188. 